\title{
The application of palm-oil waste as organic materials on three pineapple accessions cultivated on post-tin mining land in Bangka Island, Indonesia
}

\author{
TRI LESTARI", RION APRIYADI, ERIES DYAH MUSTIKARINI, WAWAN SAPUTRA, YELIA MERLIN \\ Department of Agrotechnology, Faculty of Agriculture, Fisheries and Biology, Universitas Bangka Belitung. Jl. Raya Balun Ijuk Merawang Bangka \\ 33126, Kepulauan Bangka Belitung, Indonesia. Tel./fax.: +62-717-4260048, ^email: trilestari25sm07@gmail.com
}

Manuscript received: 25 July 2019. Revision accepted: 29 January 2020.

\begin{abstract}
Lestari T, Apriyadi R, Mustikarini ED, Saputra W, Merlin Y. 2020. The application of palm-oil waste as organic materials on three pineapple accessions cultivated on post-tin mining land in Bangka Island, Indonesia. Nusantara Bioscience 12: 40-45. Tin mining activities in Bangka Island have produced a vast extent of critical lands that contain clay and tailings. Bangka local pineapple accessions have a high potential to be cultivated in the post-tin mining area as they are able to adapt to drought. The aim of this research was to investigate the growth performance of three pineapple accessions planted on post-tin mining land in Bangka by utilizing solid waste of oil palm as organic materials. The study was conducted in Dwi Makmur village, Merawang Sub-district, Bangka District from November 2017 to June 2019. The experiment used Factorial Completely Randomized Design (FCRD) with two factors: the first was three pineapple accessions (i.e. Toboali Bikang, Peranak and Bogor) and the second was palm oil solid waste (i.e. palm oil empty bunch (POEB) and palm oil bare ash (POBA)). We measured the parameters of vegetative and generative and the values were compared using Fisher test followed by Duncan Multiple Range Test $(\alpha 0.05)$. We also conducted organoleptic tests and total dissolved solid tests to assess the quality of the fruit. We found that the application of POEB as organic materials affected the vegetative and generative parameters. We also found that the interaction of POEB with Peranak accession resulted in the best fruit productivity. Our results suggest that Peranak accession is potential to be cultivated in post-tin mining land in Bangka with the application of palm oil empty bunch as organic materials.
\end{abstract}

Keywords: Accession, palm oil waste, pineapple, post-tin mining land

\section{INTRODUCTION}

Pineapple (Ananas comosus [L.] Merr) is a popular fruit that is easily found in Indonesia. This tropical fruit has high nutritional and economic value, making it an important commodity in this country (Naibaho et al. 2008). The edible part of the fruit, which is actually a multiple coalesced berry, contains high level of antioxidant in the form of vitamin A and C. It is also a source of citric and malic acid, substances that can be used to enhance flavor by masking smell. Despite the high uses, the local production of the fruit indicated a declining trend, for example in Bengkulu from 2012 to 2016. The national statistic data revealed that its production in 2012 was 24.107 tons, but it reduced to 2.266 tons in 2016 (BPS 2017).

Pineapple has fairly high adaptability to sandy soil and high intensity of solar radiation (Mustikarini 2008). Pineapple is a crassulacean acid metabolism plant, meaning that the plant is able to survive in dryland conditions and does not like waterlogged land. Due to these characteristics, pineapple is potential to be cultivated in degraded land including in post-mining area. For example, pineapple accession that can be cultivated in the post tin mining area is pineapple Toboali Bikang, Toboali Serdang, Peranak, Bogor, Australia, Ambon and Bukur (Lanoviadi, 2011).
Bangka Island has a vast extent of critical lands in the form of post tin mining land (i.e. tailings) which is not used optimally. According to Nurtjahya et al. (2017), these tailing lands contain more than $90 \%$ sand, a clay fraction of less than 3\%, and very low organic matter content. Post-tin mining land has the characteristics of low water holding capacity and washing in high sand soils (Inonu et al. 2011).

Pineapple cultivation is one alternative land use to be developed in post tin mining lands in Bangka Belitung. Despite it has the potential to increase pineapple production in the region, this effort could enhance the productivity of such critical lands caused by tin mining activities. However, since post-mining lands are generally in highly degraded conditions, various treatments are necessary to repair soil conditions (Lestari et al. 2019). For example, addition of organic materials to the critical soil is required to provide significant benefit not only to the soil availability to water and nutrients, but also to increase the activity of microorganisms in the soil that help soil fertility (Anisyah et al. 2014). It is also necessary to add organic material to increase water holding capacity and reduce porosity rates (Inonu et al. 2011).

Organic materials can be obtained from plants and animal-based waste, one of which is palm oil waste. Palmoil empty bunch (POEB) has nutrient organic materials such as $\mathrm{N}, \mathrm{P}, \mathrm{K}$, and $\mathrm{Mg}$ needed by soil and plants (Sarwono 2008). Another waste of oil palm processing is 
the ashes as the result of combustion of oil palm empty bunches. Sasli (2011) states that the ash can increase the availability of $\mathrm{N}, \mathrm{P}, \mathrm{K}, \mathrm{Ca}$ and $\mathrm{Mg}$ nutrients for plants. Palm-oil bare ash (POBA) contains nutrients such as potassium $(30-40 \%)$, phosphorus $(7 \%)$, calcium $(9 \%)$, magnesium $(3 \%)$.

This research was conducted to find out the growth of pineapple planted on post-tin mining land in Bangka by utilizing solid waste of oil palm as organic materials. In the context of Bangka, it was expected that the results of this study can contribute to enhance knowledge and provide recommendations for the potential of pineapple cultivation developed on the tailings field in Bangka since this region has a vast extent of post-tin mining land.

\section{MATERIALS AND METHODS}

\section{Study period and location}

This study was conducted from November 2018 to June 2019 in post-tin mining land PT. Timah at Dwi Makmur Village, Merawang District, Bangka Regency, Bangka Belitung Province.

\section{Materials}

The plant materials used in this research were three local Bangka pineapple accessions (i.e. Bogor, Toboali Bikang, and Peranak) which were \pm 10 months old and were obtained from West Bangka and South Bangka District. Other materials included palm oil empty bunches (POEB), palm oil bare ash (POBA), Carbide, cow manure and inorganic fertilizers (Urea, SP-36, $\mathrm{KCl}$ ).

\section{Experimental procedure}

This research used Factorial Completely Randomized Design (FCRD) with 2 factors. The first factor was treatment using a variety of palm oil solid waste and described as follow: $\mathrm{T} 0=$ Control, $\mathrm{T} 1=$ Palm Oil Empty Bunches (POEB), and T2 = Palm Oil Bare Ash (POBA). The second factor was a variety of local pineapple accession and described as follow: N1 = Toboali Bikang, N2 = Peranak, and N3 = Bogor.

All factors combined and there were nine treatment combinations. Each treatment has 3 replications so that 27 experimental units were obtained, within one experimental unit contain 24 plants and the number of samples per unit was 8 plants. Each plot had a size of $5 \mathrm{~m} \times 1.5 \mathrm{~m}$ with a spacing of $40 \mathrm{~cm} \times 80 \mathrm{~cm}$. The distance between blocks was $1 \mathrm{~m}$ and the plot is $50 \mathrm{~cm}$. Pineapple flowering was observed on pineapple plants with 10 months old or had leaves of at least 20-30 strands. The carbit stone was crushed to form small grains. As much as $1 \mathrm{~g}$ of carbit was dissolved in $250 \mathrm{ml}$ of water, then the solution was watered into pineapple plant started since planting (Hadiyati and Indriyani 2008).

\section{Parameters observed and statistical analysis}

Parameters observed were flowering time, number of crown, number of fruit eyes, length of fruit, diameter of fruit, the weight of pineapple without its crown and total dissolved solids (TDS). Organoleptic test is an activity carried out by taste testers (panelists) whose work is to observe, test, and assess organoleptically. Criteria tested are fruit color, fruit flavor, fruit texture, and fruit aroma. The panelists who did it were 20 panelists who were not experts. The assessment standards used are based on SNI 01-2346-2011, panelists assign values to the assessment sheets according to the level of product quality. The range of values is 1-7, ratings are tabulated and the quality is determined. The hedonic scale used has a range of scores ranging from 1 to 7 , namely 1 (very not like), 2 (not like), 3 (rather not like), 4 (neutral), 5 (rather like), 6 (like), 7 very like). Quantitative data were analyzed using Fisher test followed by Duncan Multiple Range Test $(\alpha=0.05)$.

\section{RESULTS AND DISCUSSION}

\section{Vegetative phase result}

Mean analysis of pineapple vegetative growth showed that the palm oil solid waste treatment had no significant effect on all observational parameters, except number of chlorophyll. Palm oil empty bunch give the highest chlorophyll content and significantly different from control and palm oil bare ash. Palm oil solid waste had not significantly different from control in plant height, number of leaves, length of leave, plant diameter and root length (Table 1).

Post-tin mining land as study site in Dwi Makmur village, Bangka district has a soil content consisting of COrganic $0.097 \%$ (low), N-total $0.001 \%$ (low), CEC 10.88 $\mathrm{cmol} / \mathrm{kg}$ (low) and sand texture $51.78 \%$, dust $40.69 \%$, clay $7.53 \%$. These results suggested the need for improvements in soil conditions on post-tin mining land. The impact of tin mining in Bangka Belitung requires reclamation studies (Nurtjahya et al. 2017). Cahyono et al. (2019) added that efforts to repair post-tin mining land can be done through a reclamation and revegetation activity with the addition of organic ameliorant and mycorrhizal fungi.

The increase in the number of leaves was the highest on average in Bikang accession can be affected by the genetic characteristics of its accession and also influenced by $\mathrm{N}$ element from organic material addition that could increase the number of leaves. This finding is in accordance with the statement of Sitio et al. (2015) that the content of $\mathrm{N}$ elements in palm oil empty bunches can cause an increase in the number of plant leaves. Nitrogen is an important and the most needed nutrient for plant growth. Nitrogen works as a constituent of amino acids, protein in the chlorophyll pigment component important in the process of photosynthesis.

Table 1. Mean analysis of the effect of palm oil solid waste on pineapple vegetative growth.

\begin{tabular}{llll}
\hline Parameter & Control & POEB & POBA \\
\hline Plant height $(\mathrm{cm})$ & $19.21 \mathrm{a}$ & $18.72 \mathrm{a}$ & $18.93 \mathrm{a}$ \\
Length of leave $(\mathrm{cm})$ & $17.67 \mathrm{a}$ & $17.52 \mathrm{a}$ & $17.25 \mathrm{a}$ \\
Number of leave $(\mathrm{strand})$ & $13.04 \mathrm{a}$ & $14.50 \mathrm{a}$ & $13.46 \mathrm{a}$ \\
Plant diameter $(\mathrm{cm})$ & $32.89 \mathrm{a}$ & $33.40 \mathrm{a}$ & $31.41 \mathrm{a}$ \\
Root length $(\mathrm{cm})$ & $27.88 \mathrm{a}$ & $31.06 \mathrm{a}$ & $31.71 \mathrm{a}$
\end{tabular}


Number of root (strand) $\quad 39.81 \mathrm{a} \quad 31.19 \mathrm{~b} \quad 29.69 \mathrm{~b}$ Number of chlorophyll (CCI) $\quad 40.61 \mathrm{~b} \quad 51.96 \mathrm{a} \quad 39.93 \mathrm{~b}$

Table 2. Duncan's multiple range test of vegetative parameters within three local Bangka pineapple accessions

\begin{tabular}{|c|c|c|c|c|c|c|c|}
\hline Parameter & Bikang & Peranak & Bogor & Parameter & Bikang & Peranak & Bogor \\
\hline Plant height $(\mathrm{cm})$ & $21.66 \mathrm{a}$ & $12.78 \mathrm{~b}$ & $22.43 a$ & Number of leave & $73.335 \mathrm{a}$ & $47.749 b$ & $72.631 \mathrm{a}$ \\
\hline Length of leave (cm) & $20.20 \mathrm{a}$ & $11.25 \mathrm{~b}$ & $20.98 \mathrm{a}$ & er of fruit eyes (unit) & $61.444 \mathrm{a}$ & $57.736 a$ & $50.038 b$ \\
\hline Number of leave (strand) & $16.17 \mathrm{a}$ & $9.19 \mathrm{~b}$ & $15.64 \mathrm{a}$ & Fruit length $(\mathrm{cm})$ & $8.5826 a$ & $8.7631 \mathrm{a}$ & $7.5927 b$ \\
\hline Plant diameter $(\mathrm{cm})$ & $31.93 \mathrm{~b}$ & $28.03 b$ & $37.64 \mathrm{a}$ & Fruit diameter $(\mathrm{cm})$ & $80.275 b$ & $86.731 \mathrm{a}$ & $79.840 \mathrm{~b}$ \\
\hline Root length $(\mathrm{cm})$ & 35.81 & 31.49 & 30.73 & ight without its crown (g) & $314.56 \mathrm{~b}$ & $408.63 a$ & $292.17 b$ \\
\hline Number of root (strand) & $37.72 b$ & $18.89 \mathrm{c}$ & $44.08 \mathrm{a}$ & Fruit weight with its crown (g) & $440.80 \mathrm{a}$ & $465.30 \mathrm{a}$ & $416.15 \mathrm{a}$ \\
\hline Number of chlorophyll (CCI) & $46.44 \mathrm{a}$ & $32.01 \mathrm{~b}$ & $54.05 \mathrm{a}$ & Flowering time (days) & $50.948 b$ & $55.198 \mathrm{a}$ & $48.406 \mathrm{~b}$ \\
\hline
\end{tabular}

The average of chlorophyll content significantly was affected by pineapple accession, which had different growth rates of root (Table 2). This is due to the condition of sandy land that had low water holding capacity. According to Hendriyani and Setiari (2009) the lack of water availability inhibited chlorophyll synthesis in leaves due to decreased rates of photosynthesis and increase in temperature and transpiration which caused the integration of chlorophyll. In addition, chlorophyll content was also influenced by nutrient $\mathrm{K}$. Each ton of POEB contains $1.5 \%$ $\mathrm{N}, 0.5 \% \mathrm{P}, 7.3 \% \mathrm{~K}$ nutrients, and $0.9 \% \mathrm{Mg}$ which can be used as fertilizer substitution for plants (Sarwono 2008).

Bogor accession had the highest growth performance on all observed parameters except for number of leaves and root length (Table 2). This result suggests that Bogor accession was able to adapt to drought stress conditions by multiplying and lengthening its roots. On the other hand, the treatment without the POEB (control) and POBA were not able to hold water and nutrients needed by pineapple plants because it was directly washed in the soil containing tin sand fraction. Djazuli (2010) stated that the plant's morpho-physiological mechanism to avoid drought stress is influenced by the ability of plants to extend their roots to find water sources far from the surface of the land when drought stress occurs in the area near the surface. Lestari et al. (2019) added that accession of 3 Bulan and Malang variety had lancet-form lobes and did not change at all irradiation dosages.

\section{Generative phase result}

The treatment of adding oil palm solid waste had significant effect on all generative parameters. POEB had significant effect on all generative parameters such as number of leave crown, number of fruit eyes, length fruit, diameter fruit, weight without its crown, weight with its crown, and flowering time.

Table 3. Duncan's multiple range test of palm oil solid waste effect on generative parameters

\begin{tabular}{llll}
\hline Parameter & Control & POEB & POBA \\
\hline Number of leave crown (strand) & $62.725 \mathrm{a}$ & $67.191 \mathrm{a}$ & $63.799 \mathrm{a}$ \\
Number of fruit eyes (unit) & $53.013 \mathrm{a}$ & $62.507 \mathrm{~b}$ & $53.698 \mathrm{~b}$ \\
Fruit length $(\mathrm{cm})$ & $8.145 \mathrm{a}$ & $8.916 \mathrm{ab}$ & $7.878 \mathrm{~b}$ \\
Fruit diameter $(\mathrm{cm})$ & 82.182 & 84.749 & 79.916 \\
\hline
\end{tabular}

A parameter representing the growth performance when entering generative phase is the formation of flowers that will become fruit. The addition of POEB had significant effect on the fruit weight, either with or without its crown (Table 3). POEB is an organic ameliorant that has a high $\mathrm{K}$ content. Each ton of POEB contains $7.3 \% \mathrm{~K}$ nutrients, which can be used as fertilizer substitution for plants. Supplementing $\mathrm{K}$ is also able to increase the yield of dry biomass significantly compared with the control (Syakir and Gusmaini 2012). Another study in tomato by Nugroho (2012) also found that $\mathrm{K}$ can increase fruit weight per plant.

According to Safuan (2011), pineapple plants require large amounts of $\mathrm{K}$ to metabolize carbohydrates and nitrogen for normal functioning of the stomata. Photosynthetic activity will decrease when $\mathrm{K}$ nutrient reduced, resulting in a decrease in plant growth and fruit weight. This shows the flowering time of each variety will show different characteristics depending on the genetic characteristics of each pineapple variety. In addition to genetics, the application of $\mathrm{P}$ and $\mathrm{K}$ fertilizers can affect the generative development of plants, because the elements $\mathrm{P}$ and $\mathrm{K}$ help in the emergence of flowering (Mustaqim 2016). K fertilizer (potassium) supports plant growth, flowering, and fruit formation.

Accession of Bikang showed the highest performance in terms of the number of fruit eyes, while accession of Bogor showed the shortest flowering time (Table 4). The lowest pineapple weight without its crown resulted from Bogor accession and the longest flowering time is Peranak accession. Based on the data displayed Peranak accession shows the best treatment compared to other accession treatments. Based on the parameter of flowering time, the accession factor had significant effect. Bogor accession had the fastest flowering time at 48 days after application (DAA). Bogor pineapple accession is Queen pineapple group, and our result corresponds to the research of Syah et al. (2015) in which the treatment of various dosages of NPK tablet fertilizer resulted in the period of flowering of Queen pineapple varieties ranging from 42 to 46 days after application (DAA). Bogor accession which belongs to Queen varieties has a flowering time which is relatively faster compared to other pineapple accessions used in this study. The results of the research by Hadiati et al. (2011) 
showed that when the flowering was spurred, the Cayenne group flowered 1-2 weeks slower than the Queen and Spanish groups.

Peranak accession showed the highest performance on several parameters such as fruit length, fruit diameter, fruit weight without its crown, fruit weight with its crown and flowering time. Based on research by Lanoviadi et al. (2011), Peranak pineapple had the highest number of plot production on large and medium seedlings, while Bikang pineapple had the lowest weight. These results suggest that Peranak accession remains consistent in fruit yield if planted on post-tin mining land. Peranak accession belongs to the Cayenne group, which is a group that is large in size and has a high fruit weight. This is consistent with the research by Hadiati et al. (2011) which found that Simadu varieties (Cayenne Group) have the largest fruit weight and were significantly different from Q, EE, P, and Ponggok varieties.

The application of POEB had effect on the performance of local Bangka accessions planted on post-tin mining land (Table 5). The POEB when making biochar-microbes can maintain soil $\mathrm{pH}$, improve nutrient retention of $\mathrm{P}$ and $\mathrm{K}$, and provide nutrients $\mathrm{N}, \mathrm{P}, \mathrm{K}$. Besides improving soil chemical properties, POEB fibers can also improve soil physical properties. According to Hatta et al. (2014), POEB compost can improve soil structure to be loose, help with nutrient solubility needed by plants, be homogeneous, and reduce the risk of carrying plant pests. The application of ameliorants (mineral soils, organic fertilizers, and lime) and NPK fertilization on the former tin mining land improved the physical and chemical properties of the soil.

The application of POEB on Peranak accession yielded the highest mean values for fruit weight parameter (weight without crown), fruit length and fruit diameter (Table 5). According to Lanoviadi (2011), the parameters of fruit length and fruit diameter give the highest yield. These results suggest that the treatment of POEB can increase the availability of $\mathrm{N}, \mathrm{P}$ and $\mathrm{K}$ in the soil. Organic materials derived from POEB compost can facilitate the absorption of nitrogen by plants, namely nitrate and ammonium (Asra et al. 2015). $\mathrm{N}$ and $\mathrm{K}$ elements play a role in the formation of proteins and carbohydrates and strengthen plant tissues. Deficiency of these elements can cause improper growth of fruit, small size and low quality which results in low efficiency (Syah et al. 2015). Adding POEB compost on alluvial soil makes soil $\mathrm{pH}$ in appropriate level and the nutrients become available for turnip plants so that they can be absorbed by roots for photosynthesis (Santi et al. 2018). The photosynthate produced will be transferred and stored in the fruit. Elumalai et al. (2002) in Suwanti et al. (2014) suggested that potassium is needed for the accumulation and translocation of newly formed carbonates from photosynthesis. Element $\mathrm{K}$ plays an important role in plant metabolism, among others, is directly involved in several physiological processes. Potassium plays a role in controlling osmotic pressure, cell turgor, $\mathrm{pH}$ stability, and water regulation through stomata control (Farhad et al. 2010).

Tabel 5. Duncan's multiple range test of the palm oil solid waste effect on generative parameters in three local Bangka pineapple accessions.

\begin{tabular}{lcccccc}
\hline \multicolumn{1}{c}{ Treatment } & $\begin{array}{c}\text { Number of } \\
\text { leave crown }\end{array}$ & $\begin{array}{c}\text { Weight without } \\
\text { its crown }\end{array}$ & $\begin{array}{c}\text { Weight with } \\
\text { its crown }\end{array}$ & $\begin{array}{c}\text { Number of fruit } \\
\text { eyes }\end{array}$ & $\begin{array}{c}\text { Fruit } \\
\text { Diameter }\end{array}$ & Fruit Length \\
\hline Control + Bikang & $71.917 \mathrm{a}$ & $313.73 \mathrm{bc}$ & $430.19 \mathrm{abc}$ & $62.733 \mathrm{ab}$ & $79,818 \mathrm{abc}$ & $90,784 \mathrm{a}$ \\
Control + Peranak & $43.067 \mathrm{~b}$ & $332.27 \mathrm{bc}$ & $377.67 \mathrm{bc}$ & $40.867 \mathrm{c}$ & $86,068 \mathrm{ab}$ & $78,507 \mathrm{ab}$ \\
Control + Bogor & $73.190 \mathrm{a}$ & $306.65 \mathrm{bc}$ & $437.23 \mathrm{abc}$ & $55.440 \mathrm{ab}$ & $81,276 \mathrm{abc}$ & $75,054 \mathrm{ab}$ \\
POEB + Bikang & $77.214 \mathrm{a}$ & $364.38 \mathrm{abc}$ & $508.88 \mathrm{ab}$ & $66.017 \mathrm{a}$ & $82,675 \mathrm{abc}$ & $87,668 \mathrm{a}$ \\
POEB + Peranak & $46.746 \mathrm{~b}$ & $479.35 \mathrm{a}$ & $543.35 \mathrm{a}$ & $54.290 \mathrm{ab}$ & $88,673 \mathrm{a}$ & $93,834 \mathrm{a}$ \\
POEB + Bogor & $77.613 \mathrm{a}$ & $384.4 \mathrm{abc}$ & $495.46 \mathrm{ab}$ & $67.214 \mathrm{a}$ & $82,899 \mathrm{abc}$ & $85,978 \mathrm{a}$ \\
POBA + Bikang & $70.875 \mathrm{a}$ & $265.58 \mathrm{c}$ & $383.33 \mathrm{bc}$ & $55.583 \mathrm{ab}$ & $78,333 \mathrm{bc}$ & $79,025 \mathrm{ab}$ \\
POBA + Peranak & $53.433 \mathrm{~b}$ & $414.27 \mathrm{a}$ & $474.88 \mathrm{ab}$ & $54.958 \mathrm{ab}$ & $86,068 \mathrm{ab}$ & $90,551 \mathrm{a}$ \\
POBA + Bogor & $67.089 \mathrm{a}$ & $221.46 \mathrm{c}$ & $315.76 \mathrm{c}$ & $50.554 \mathrm{bc}$ & $75,346 \mathrm{c}$ & $66,749 \mathrm{~b}$ \\
\hline
\end{tabular}

Tabel 6. Results of the organoleptic test of three local Bangka pineapple accessions with application of solid palm oil waste

\begin{tabular}{|c|c|c|c|c|}
\hline Treatment & Color & Fragrance & Flavors & Texture \\
\hline Control + Bikang & Neutral & Rather Like & Rather Like & Rather Like \\
\hline Control + Peranak & Rather Like & Rather Like & Rather Like & Rather Like \\
\hline Control + Bogor & Rather Like & Rather Like & Rather Like & Rather Like \\
\hline POEB + Bikang & Rather Like & Rather Like & Rather Like & Rather Like \\
\hline POEB + Peranak & Rather Like & Rather Like & Rather Like & Rather Like \\
\hline POEB + Bogor & Rather Like & Rather Like & Rather Like & Rather Like \\
\hline POBA + Bikang & Neutral & Rather Like & Neutral & Rather Like \\
\hline POBA + Peranak & Rather Like & Rather Like & Neutral & Rather Like \\
\hline POBA + Bogor & Neutral & Neutral & Neutral & Neutral \\
\hline
\end{tabular}




\section{REFERENCES}

Tabel 7. Results of total dissolved solid test of three local Bangka pineapple accessions with application of solid palm oil waste

\begin{tabular}{lc}
\hline Treatment & $\begin{array}{c}\text { Total Dissolved Solid } \\
\text { (TDS) }\end{array}$ \\
\hline Control + Bikang & $\mathbf{1 3 . 9 3 3 a}$ \\
Control + Peranak & $12.967 \mathrm{a}$ \\
Control + Bogor & $12.067 \mathrm{a}$ \\
POEB + Bikang & $13.067 \mathrm{a}$ \\
POEB + Peranak & $12.567 \mathrm{a}$ \\
POEB + Bogor & $13.4 \mathrm{a}$ \\
POBA + Bikang & $13.067 \mathrm{a}$ \\
POBA + Peranak & $12.967 \mathrm{a}$ \\
POBA + Bogor & $10.533 \mathrm{a}$ \\
\hline
\end{tabular}

Based on the organoleptic test it was found that the use of POBA provided an average value of 4 (Neutral). The use of POEB showed a value of 5 (Rather Like) which means the level of preference of panelists for pineapple tested achieved higher value (table 6). This is presumably because the value of TDS in POEB applications was higher than POBA (Table7). High TDS values indicated more sugar content in POEB treatment, meaning that the panelists had a preference for a sweeter than tamarind which tends to sour. This is consistent with the statement of Abdi et al (2017) that sugar levels have a large role in the appearance and taste of fruit juice. Each product has a specific taste that varies depending on the constituent material (Nurlaila et al. 2013).

The range of TPT values ranged between $10.5^{\circ}$ Brix$13.9^{\circ}$ Brix (Table 7). The Peranak accession (Cayenne group) showed the lowest value of TPT compared to Bikang pineapple accession and Bogor pineapple accession (Queen group). Based on the research of Hadiati and Yuliati (2010), Queen pineapple group has a higher TPT value compared to the Cayenne group. The evaluation results in Solok showed that accession Q (Queen Group) had TPT $16.31^{\circ}$ Brix (Hadiati and Yuliati 2010).

In conclusion, the addition of palm oil solid waste as organic materials and pineapple accession had an effect on the performance of pineapple. We found that Peranak accession treated with the application of palm oil empty bunch (POEB) provide the highest yield. As such we recommend that Peranak accession is potential to be cultivated in post-tin mining land in Bangka with the application of palm oil empty bunch (POEB).

\section{ACKNOWLEDGEMENTS}

The authors are grateful for financial support from the Ministry of Research Technology and Higher Education, the Republic of Indonesia for Applied Research Grant 2019 and PT Timah Tbk.
Abdi YA, Rostiati, Kadir S. 2017. Physical-chemical and organoleptic quality of tomato fruit (Lycopersicum esculentum Mill.) coating resulted by various types of starch during storage. Jurnal Agrotekbis 5 (5): 547-553. [Indonesian]

Anisyah F, Sipayung R, Hanum C. 2014. Growth and yield of shallot with some of organic fertilizer application. Jurnal Online Agroekoteknologi 2 (2): 482-496. [Indonesian]

Asra G, Simanungkalit T, Rahmawati N, 2015. Response a giving compost oil palm empty fruit bunch and zeolite toward oil palm seed growth in pre nursery. Jurnal Online Agroekoteknologi 3 (1): 416426. [Indonesian]

BPS [Badan Pusat Statistik]. 2017. Data Produksi Nenas 2012-2016. www.bps.co.id (23 Maret 2018). [Indonesian]

Cahyono A, Primanada E, Faridah D, Wulandari Lestari T. 2018. Role of arbuscular mycorrhizal fungi and Pongamia pinnata for revegetation of tropical open-pit coal mining soils. Intl J Environ Sci Technol 16 (7): 3365-3374. [Indonesian]

Djazuli M. 2010. Pengaruh cekaman kekeringan terhadap pertumbuhan dan beberapa karakter morfo-fisiologis tanaman nilam. Balai Penelitian Tanaman Obat Dan Aromatik 21 (1): 8-17. [Indonesian]

Farhad ISM, Islam MN, Hoque S, Bhuiyan MSI. 2010. Role of potassium and sulphur on the growth, yield, and oil content of soybean (Glycine $\max$ L.). Ac J Plant Sci 3 (2): 99-103.

Hadiati S, Indriyani NLP. 2008. Petunjuk Teknis Budidaya Nenas. Balai Penelitian Tanaman Buah Tropika, Solok. [Indonesian]

Hadiati S, Yuliati S, Jumjunidang. 2011. Evaluation of growth and yield on several candidates of pineapple varieties with low oxalate content and sweet taste with spineless leaves. Jurnal Hortikultura 21 (4): 315 323. [Indonesian]

Hadiati S, Yuliati S. 2010. Evaluasi Kandidat Nenas Rendah Oksalat. [Prosiding] Seminar Nasional Program dan Strategi Pengembangan Buah Nusantara, Solok 10 November 2010. [Indonesian]

Hendriyani IS, Setiari N. 2009. Kandungan klorofil dan pertumbuhan kacang panjang (Vigna sinensis) pada tingkat penyediaan air yang berbeda. Jurnal Sains \& Matematika 17 (3): 145-150. [Indonesian].

Inonu I, Budianta D, Harun MU, Yakup, Wiralaha. 2011. Amelioration of organic materials on sand tailings media derived from tin-postmining for rubber seedling growth. Jurnal Agrotropika. 16 (1): 45-51.

Lanoviadi A, Mustikarini ED, Widyastuti. 2011. The adaptability and production of lokal pineapple of bangka on the sandy tailing land of tin mining activities. Enviagro Jurnal Pertanian dan Lingkungan 4 (1): 1-48. [Indonesian]

Lestari T, Mustikarini ED, Apriyadi R, Anwar S. 2019. Early stability test of mutant candidates of Bangka local cassava, Indonesia. Biodiversitas 20 (1): 337-342.

Masganti, Wahyunto A, Dariah, Nurhayati, Rachmiwati. 2014. Characteristics and potential utilization of degraded peatlands in Riau Province. Jurnal Penelitian dan Pengembangan 8 (1): 47-54. [Indonesian]

Mustaqim R, Armaini, Yulia AE. 2016. The effect compost of oil palm empty fruit bunches and $\mathrm{N}, \mathrm{P}$, and $\mathrm{K}$ fertilizer on growth and production of melon (Cucumis melo L.). JOM Faperta 1 (3). [Indonesian]

Mustikarini ED. 2008. Analisis keragaman morfologi dan RAPD tujuh tanaman nenas lokal Bangka di lahan bekas penambangan timah. Enviagro. Jurnal Pertanian dan Lingkungan 2 (1) [Indonesian]

Naibaho N, Darma K, Sobir, Suhartanto MR. 2008. Perbanyakan Massal Bibit Nenas dengan Stek Daun. Pusat Kajian Buah Tropika, LPPM IPB, Bogor. [Indonesian]

Nugroho. 2012. Peran konsentrasi pupuk daun dan dosis pupuk kalium terhadap hasil tanaman tomat (Lycopersicum esculentum Mill). J Politeknosains Edisi Khusus Dies Natalis.: 35-43 [Indonesian]

Nurlaila EH, Santoso J, Salamah L. 2013. Effects of carrageenan coating on organoleptic quality of boiled shrimp during refrigeration storage. Jurnal Agroindustri 3: 1-7. [Indonesian]

Nurtjahya E, Franklin J, Umroh, Agustina F. 2017. The impact of tin mining in Bangka Belitung and its reclamation studies. Matec Web of Conferences 1-6. [Indonesian]

Safuan LOR, Poerwanto AD, Susila, Sobir. 2011. The effect of soil potassium status on the growth and production of pineapple. Jurnal Agronomi. Indonesia 39 (1): 56-61. [Indonesian] 
Santi A, Rahayuni T, Santoso E. 2018. Effect of empty fruit bunches of oil palm compost on growth and yield of radish on alluvial soil. Jurnal Untan 1: 30-33. [Indonesian]

Sarwono E. 2008. Pemanfaatan Janjang Kosong Sebagai Substitusi Pupuk Tanaman Kelapa Sawit. Jurnal Aplika 8 (1): 19-23 [Indonesian]

Sasli I. 2011. Karakterisasi gambut dengan berbagai bahan amelioran dan pengaruhnya terhadap sifat fisik dan kimia guna mendukung produtivitas lahan gambut. Agrovigor 4 (1): 42-50. [Indonesian]

Sitio Y, Wijana G, Raka IGN. 2015. The utilization of oil palm empty bunches and nitrogen fertilizer as substitution of topsoil on growth of oil palm seedling (Elaeis guineensis Jacq.) in pre-nursery. E-Jurnal Agroekoteknologi Tropika. 4 (4): 264-273. [Indonesian]

Suwanti, Susilo J, Baskara M, Wicaksono KP. 2017. Response of flowering and yield of pineapple (Ananas comosus (L.) Merr) cv
Smooth cayenne for fertilizer reduction and ethylene application. Jurnal Produksi Tanaman 5 (8): 1346-1355. [Indonesian]

Syah MAI, Anom E, Putra SI. 2015. The effect of giving multiple doses of NPK fertilizer tablet to growth and production of pineapple (Ananas comosus (L) Merr) in peatland. Jurusan Agroteknologi, Fakultas Pertanian, Universitas Riau. Jurnal Online Mahasiswa Faperta 2 (1): 1-8. [Indonesian]

Syakir M, Gusmaini. 2012. Effect of potassium sources on application yield and quality of patchouli. Jurnal Littri 18 (2): 60-65.

Yunindanova MB, Agusta H, Asmono D. 2013. The effect of maturity level of empty fruit bunch compost and mulch from palm oil waste to tomato (Lycopersicon Esculentum Mill.) productivity in ultisol. Sains Tanah-Jurnal Ilmu Tanah dan Agroklimatologi 10: (2). [Indonesian] 